\title{
Potential Use of Zooplankton as Ecological Quality Indicator According to Water Framework Directive (WFD) in Central Brazilian Reservoir
}

\author{
Claudia Padovesi-Fonseca* \\ Departamento de Ecologia, Universidade de Brasília, Brazil
}

Submission: November 29, 2019; Published: January 06, 2020

Corresponding author: Claudia Padovesi-Fonseca, Departamento de Ecologia, Universidade de Brasília Group of Limnological Studies (NEL), Brazil

\begin{abstract}
Zooplankton species have high sensibility to environmental changes and impacts, leading to shifts in composition and diversity of the communities and associated to increase of biodiversity, with a high potential to endemism. With the implementation of the European Water Framework Directive (WFD), there was the ecological status classification of surface waters based on the assessment of series of biological quality elements $(\mathrm{BQE})$ and supported by a set of chemical and hydro morphological quality data. Despite zooplankton have being considered a key component in pelagic food web, with a significant biological indicator of water quality, this group was not included at the first moment for the WFD evaluation. The ecological potential and the chemical status of an urban Brazilian reservoir (Lake Paranoá) during a eutrophic and restoration periods, represent a robust case study for the inclusion of zooplankton as a BQE in the WFD. This reservoir had a negative history on the water quality and for three decades (1968-1998) it was subjected to intense eutrophication. With the water quality restoration process and intentional flushing, changes in the plankton assemblages have been detected. During eutrophicated period, there were a dominance of detritivores microzooplankton and high biomass; and after recovery process, zooplankton biomass had a conspicuous decline accompanied to dominance of herbivorous larger bodies species. This study constitutes the first proposal to be done in central region of Brazil.
\end{abstract}

Keywords: Brazil; Cerrado; Aquatic biodiversity; Water quality; Lake restoration.

Abbreviations: WFD: European Water Framework Directive; BQE: Biological Quality Elements.

\section{Introduction}

The use of biological communities on ecosystems classification as well on monitoring program can intend to access their ecological assessment. It can be got to applying multimeric and predictive models [1-3]. Nowadays have been an increasing demand for effective monitoring methods based on biotic indices [46]. With the implementation of the European Water Framework Directive (WFD), there was the ecological status classification of surface waters based on the assessment of series of biological quality elements (BQE) and supported by a set of chemical and hydro morphological quality data [7]. Various biological groups were included in the WFD analysis, such as phytoplankton, aquatic macrophytes macroinvertebrates and fishes [8-11]. Despite zooplankton have being considered a key component in pelagic food web with a significant biological indicator of water quality this group was not included at the first moment for the WFD evaluation. Indeed, zooplankton species have high sensibility to environmental changes and impacts, leading to shifts in composition and diversity of the communities associated to increase of biodiversity, with a high potential to endemism [12-15]. Claimed for the inclusion of zooplankton as a BQE in the WFD because they could even the best quality indicators than other BQE [16].

\section{The Inclusion of Zooplankton as Ecological Indicator} in Central Brazil Reservoir

Brazilian Central Plateau is covered by Cerrado. This neotropical savannah is recognized as a relevant world's biodiversity hotspot, being biologically the richest one and with a high 
degree of endemism, as review by [17]. The central Brazilian region is considered the "water cradle" of Brazil, with important springs from South American watersheds. High biodiversity and endemism associated with water human sources has made this region an important area for the conservation with a further sustainable human use. Anthropic activities have caused several impacts on drainage-basins, as water pollution and silting of running waters, affecting riparian and aquatic biota. More than half of the vegetation cover of the Cerrado was replaced by pastures and agriculture, in addition to urbanization [18].

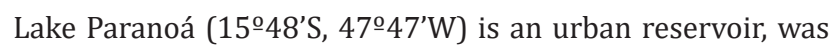
built in 1959 to provide recreation activities, power generation and enhance the microclimate in Brazil's Federal Capital, Brasilia. It is situated in the Central Brazilian Plateau, at an altitude 1,000 $\mathrm{m}$, with surface area $38 \mathrm{~km}^{2}$, volume $498.6^{*} 10^{6} \mathrm{~m}^{3}$, max. depth $40 \mathrm{~m}$, mean depth $13 \mathrm{~m}$. The reservoir had a negative history on the water quality and for three decades it was subjected to intense eutrophication, culming to application of copper sulfate to control cyanobacteria blooms [19]. It was subjected to intense eutrophication for 30 years 1968-1998), due mainly to human occupation of the catchment area and nutrients inflow derived to inadequate sewage treatment, especially since 1970's [20].

For three decades, there were a dominance of detritivores microzooplankton and a monoculture of filamentous blue green algae, Cylindrospermopsis raciborskii (Woloszynska) Seenayya \& Subba Raju, 1972 as well as blooms of Microcystis aeruginosa (Kützing) Kützing, 1846 [19]. Also, there were observed extended areas of aquatic macrophytes (Eichhornia crassipes) and frequent fish kills were observed during this period. Since 1993 nutrient loading in Paranoá reservoir has been reduced, as a result of the operation of a new sewage treatment system and a water quality restoration process [20]. Besides of this, there were no obvious changes in the zooplankton community, and the predominance of species usually related to eutrophicated systems [21].

After intentional flushing occurred in 1998, the reservoir had a consequent water quality improvement [20]. After this event, changes in the plankton assemblages have been detected. In this scenario of adjustments between environmental conservation and human uses of water, it is necessary meets its goals to ensure the availability of adequate water quality standards for current and future generations and promote the rational and integrated use of water resources. The flushing event produced a pronounced and fast response of zooplankton assemblages. Zooplankton biomass had a conspicuous decline accompanied to dominance of herbivorous larger bodies species, as Calanoida and daphnids. Temporal trends during the eutrophicated and after flushing periods in Lake Paranoá were marked in relation to zooplankton biomass and their groups (Figures 1 and 2).

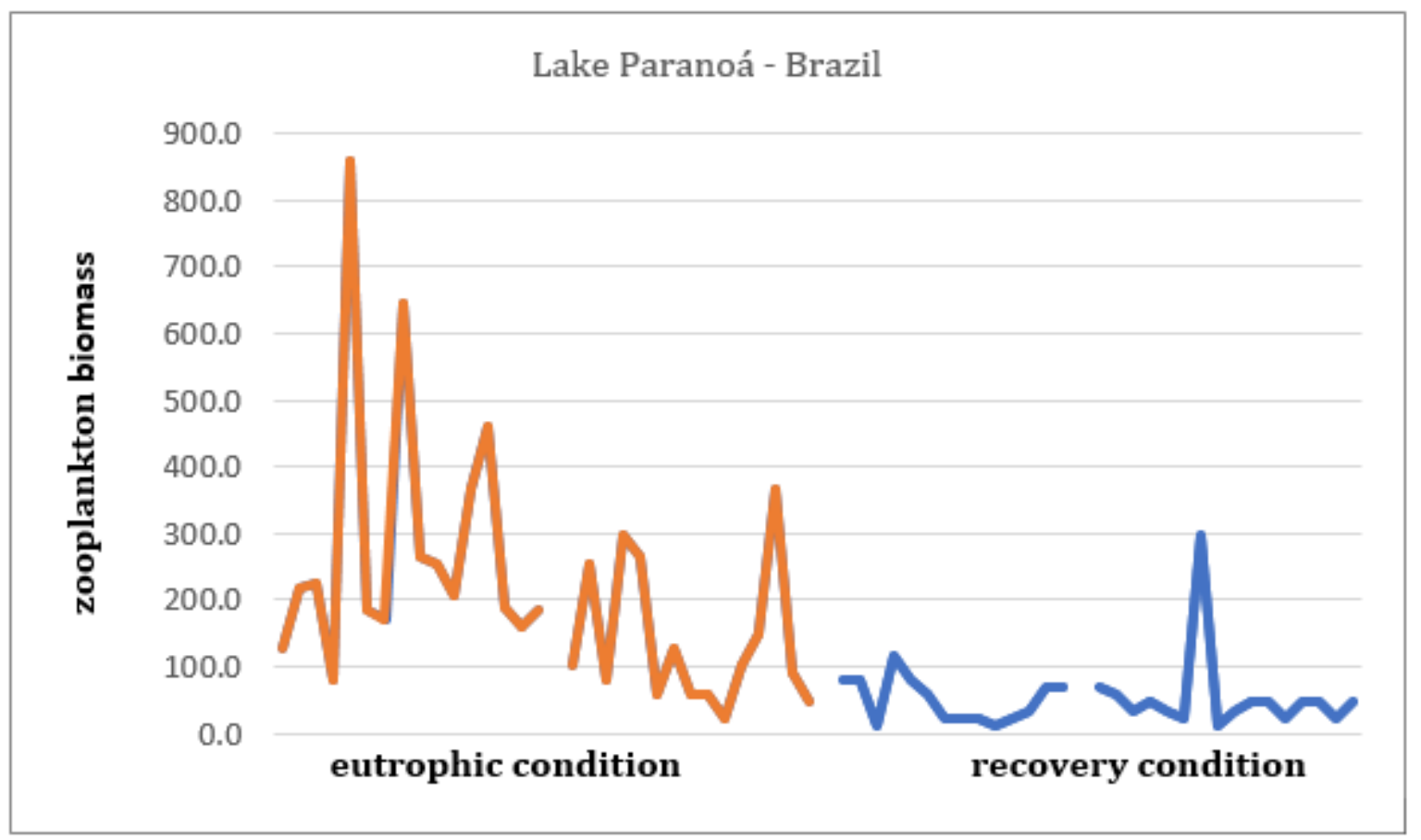

Figure 1: Temporal trends during eutrophic (1996-1997) and recovery (1999-2000) conditions, Lake Paranoá, central Brazil. 


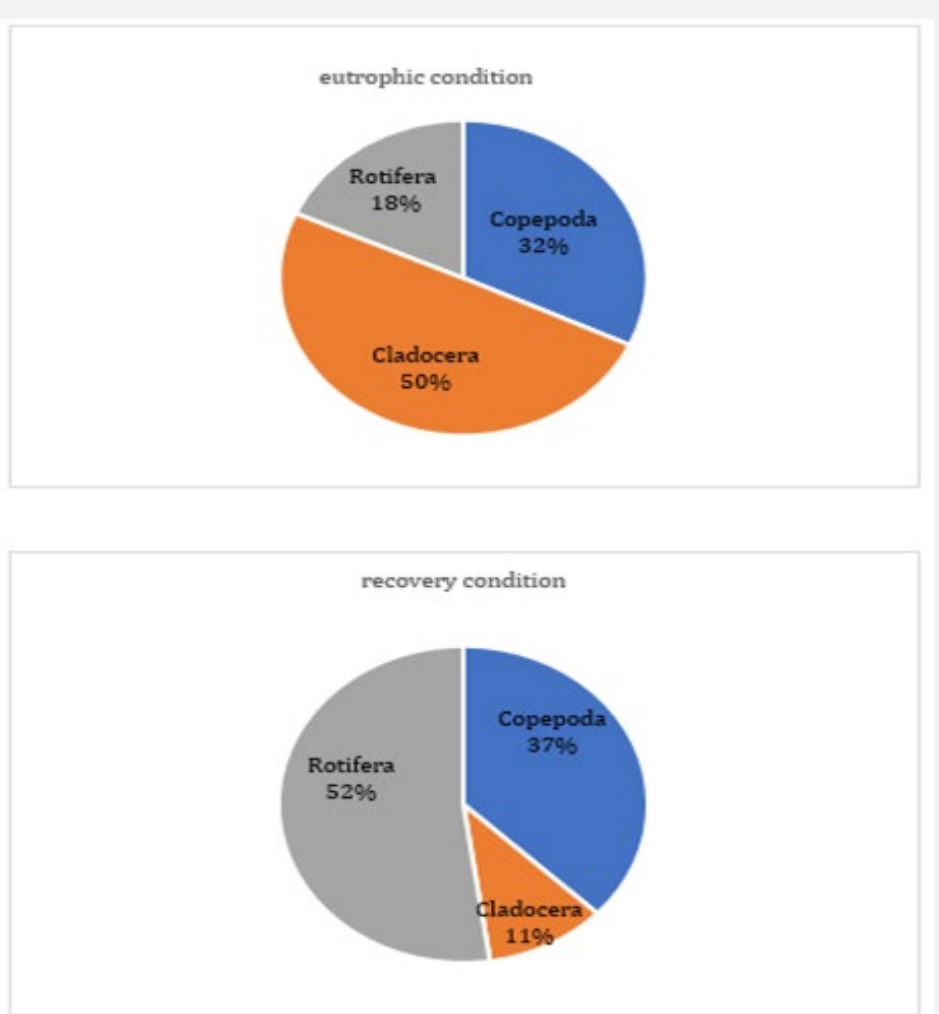

Figure 2: Density zooplankton groups (\%) during eutrophic (1996-1997) and recovery (1999-2000) conditions, Lake Paranoá, central Brazil

In the Water Framework Directive (WFD), the European water resources management system, the water quality is not linked to the use, but to the ecological quality of the environment. The WFD adopts ecosystem approach in order to the water bodies achieve minimal degradation state. In 'good conditions', physical, chemical, biological and hydro morphological conditions, the waterbodies have 'slight' deviation from those without human action. For the reservoirs, the WFD allows to identify and designate artificial and heavily modified water bodies, and the goal is to achieve good ecological potential and good chemical status for surface waters, considering the objectives for the uses of these reservoirs.

\section{Conclusion}

The use of aquatic biota constitutes the biological quality element for the ecosystem evaluation as well as further monitoring and generating new scenarios. The ecological potential and the chemical status of an urban reservoir (Lake Paranoá) during an eutrophic and recovery periods (after flushing event), taking into account the basin uses and its occupation for each evaluated period represent a robust case study for the inclusion of zooplankton as a BQE in the WFD. In Brazil, there are few studies based on the WFD, and this study constitute the first proposal to be done in central region of Brazil. Zooplankton were not included as biological quality element (BQE) in the implementation of WFD, although zooplankton may be a cost-efficient indicator of the ecological quality for reservoirs.

\section{References}

1. Kane DD, Gordon SI, Munavar M, Charlton MN, Culver DA (2009) The Planktonic index of biotic integrity (P-1131): an approach for assessing lake ecosystem health. Ecological Indicators 9: 1234-1247.

2. Blank K, Laugaste R, Haberman J (2010) Temporal and spatial variation in the zooplankton: phytoplankton biomass ratio in a large shallow lake. Estonian Journal of Ecology 59: 99-115.

3. Ejsmont-Karabin J (2012) The usefulness of zooplankton as lake ecosystem indicators: rotifer trophic index. Polish Journal of Ecology 60: 339-350.

4. Duggan IC, Green JD, Shiel RJ (2001) Distribution of rotifers in North Island, New Zealand, and their potential use as bioindicators of lake trophic state. Hydrobiologia 446(1): 155-164.

5. Haberman J, Laugaste R (2003) On characteristics reflecting the trophic state of large and shallow Estonian lakes (L. Peipsi L. Võrtsjärv). Hydrobiologia 506: 737-744.

6. Carpenter KE, Johanson JM, Buchanan C (2006) An index of biotic integrity based on summer polyhaline zooplankton community of the Chesapeake Bay. Maine Environmental Research 62(3): 165-180.

7. EC- European Commission (2012) Report from the Commission to the European Parlament and the Council on the Implementation of the Water Framework Directive (2000/ 60/EC). River Basin Management Plans. Brussels 15. 
8. Spatharis, S, Tsirtsis, G (2010) Ecological quality scales based on phtytoplankton for the implementation of Water Framework Directive in the Eastern Mediterranean. Ecological Indicators 10(4): 840-847.

9. Coops FC M, Kerkum EM S, Van den Berg EI, Van Splunder H (2007) Submerged macrophyte vegetation and the European Water Framework Directive: assessment of status and trends in shallow, alkaline lakes in the Netherlands. Hydrobiologia 584: 395-402.

10. Birk S, Hering D (2009) Direct comparison of assessment methods using benthic macroinvertebrates: a contribution to the EU Water Framework Directive intercalibration exercise. Hydrobiologia 566 401-415.

11. Uriarte A, Borja A (2009) Assessing fish quality status in transitional waters, within the European Water Framework Directive: Setting boundary classes and responding to anthropogenic pressures. Estuarine, Coastal and Shelf Science 82(2): 214-224.

12. Caroni R, Irvine K (2010) The potential of zooplankton communities for ecological assessment of lakes: redudant concept or political oversight?. Biology and Environment Proceedings of the Royal Irish Academy 110(1): 35-53.

13. Davidson T, Bennion AH, Jeppesen E, Clarke GH, Sayer C, et al. (2011) The role of cladocerans in tracking long-term change in shallow lake trophic status. Hydrobiologia 676: 299-315.

14. Xiong W, Li J, Chen Y, Shan B, Wang W, et al. (2016) Determinants of community structure of zooplankton in heavily polluted river ecosystems. Scientific Reports 6(1): 22-43.
15. Leibowitz SG (2003) Isolated wetlands and their functions: An ecological perspective. Wetlands 23(3): 517-531.

16. Jeppesen E, Nõges P, Davdson TA, Haberman J, Nõges T, et al. (2011) Zooplankton as indicators in lakes: a scientific-based plea for including zooplankton in the ecological quality assessment of lakes according to the European Water Framework Directive (WFD). Hydrobiologia 676: 279-297.

17. Padovesi-Fonseca C, Martins-Silva MJ, Puppin-Gonçalves CT (2015) Cerrado's areas as a reference analysis for aquatic conservation in Brazil. Biodiversity Journal 6: 805-816.

18. Klink CA, Machado RB (2005) Conservation of the brazilian Cerrado. Conservation biology 19(3): 707-713.

19. Padovesi-Fonseca C, Philomeno MG (2004) Effects of algicide (Copper Sulfate) application on short-term fluctuations of phytoplankton in Lake Paranoa, Central Brazil. Brazilian Journal of Biology 64(4): 819826

20. Padovesi-Fonseca C, Philomeno MG, Andreoni-Batista C (2009) Limnological features after flushing event in Paranoá Reservoir, central Brazil. Acta Limnologica Brasiliensia 21: 277-285.

21. Padovesi-Fonseca C, Mendonça-Galvão L, Rocha DLP (2002) Temporal fluctuation and reproduction of Thermocyclops decipiens (Copepoda, Cyclopoida) in a eutrophic lake of Central Brazil. Rev Biol Trop 50(1): 57-68.

\section{Your next submission with Juniper Publishers will reach you the below assets}

- Quality Editorial service

- Swift Peer Review

- Reprints availability

- E-prints Service

- Manuscript Podcast for convenient understanding

- Global attainment for your research

- Manuscript accessibility in different formats

( Pdf, E-pub, Full Text, Audio)

- Unceasing customer service

Track the below URL for one-step submission https://juniperpublishers.com/online-submission.php 